\title{
Optimization of process variables for treatment of food industry effluents by electrocoagulation
}

\author{
Veli S., Özbay I. *, Özbay B., Arslan A. and Çebi E. \\ University of Kocaeli, Department of Environmental Engineering, 41380 Kocaeli, Turkey \\ Received: 23/02/2018, Accepted: 09/06/2018, Available online: 26/09/2018 \\ *to whom all correspondence should be addressed: e-mail: iozbay@kocaeli.edu.tr \\ https://doi.org/10.30955/gnj.002640
}

\begin{abstract}
The present study investigates the process optimization for treatment of potato processing industry wastewater by electrocoagulation. Performance of treatability was evaluated by achieved chemical oxygen demand (COD) removal efficiencies. Response Surface Methodology was applied to determine individual and interactive impacts of the selected operation variables $(\mathrm{pH}$, conductivity, current density and duration period) on COD removal. Optimization studies were also performed for energy consumption costs which still remain as the major drawback of the electrocoagulation applications. Interactions between dependent and independent process variables were interpreted by the relevant surface plots. Sufficient correlation coefficients were obtained for the predictive regression models of the optimization. Results of the ANOVA tests showed that both of the models are statistically significant. Impacts of the process parameters on response values have been evaluated numerically by Pareto analysis. Furthermore, validation studies were conducted to confirm the accuracy of the model developed for prediction of COD removal efficiencies.
\end{abstract}

Keywords: Central composite design, COD removal, electrocoagulation, energy consumption costs, food industry effluents, Pareto analysis.

\section{Introduction}

Similar to the many other engineering fields, environmental treatment applications involves multifactorial processes. Determination of optimum conditions is essential in order to achieve higher removal efficiencies with lower cost, energy, time, etc. Until recent years, "one at a time" variation of process variables was applied to optimize the treatment processes (Raj and Quen, 2005). This conventional approach proposes examination impacts of one selected parameter by keeping all others constant. So, determination of optimum conditions demands numerous time-consuming tests, especially in case of large numbers of variable. In addition, current techniques are incapable to analyze the interactive effects of multiple variables on targeted responses (Rathinam et al., 2011; Pakvaran et al., 2015).

In order to overcome the mentioned deficiency and shortcomings of conventional optimization technique, factorial design methodologies have been developed. On contrary to "one at a time" approach, these methods provide knowledge about the impacts of several factors at two or more levels (Wang and Wan, 2009). In this way, both individual and interactive impacts of the variables can be analyzed (Dashamiri, 2016). As actual conditions are better represented by taking interactive effects into account, the error in the experimental tests can be minimized.

The factorial design methods are categorized into two major groups as the full factorial and the fractional factorial design. The full factorial design investigates each and every combination of input parameters. Even though this methodology enables the examination of all possible combinations, the number of the required experiments rises by the increase in factor and level numbers. On the other hand, the fractional factorial method involves experiments that make them more beneficial, especially in the case of large number of runs. Taguchi-centralcomposite and Box-Behnken design are some of the wellknown fractional factorial design procedures. Taguchi approach is based on an experimental data transformation method, which is the measure of the present response variations (Elizalde-González and GarcíaDíaz, 2010). In this method, the signal-to-noise ratio is used as a quality characteristic and evaluation measurement tool for the impacts of each selected factor on the responses (Dongxia et al., 2012). Despite this approach's simplicity, the difficulty of taking interactions into account poses a potential problem during application (Tsui, 1996). Thus, selection of levels for the studied factors requires significant experience about the topic.

Considering the mentioned drawbacks of Taguchi, other fractional factorial methods such as central composite (CCD) and Box-Behnken design (BBD) become more favorable. Comparing these two methods, BBD provides the advantage of demanding fewer experiments. On the other hand, CCD enables knowledge about the responses 
at extreme conditions which cannot be achieved by using BBD (Gengec et al., 2013; Nikzad et al., 2015).

In experimental design studies, The Pareto analysis is a useful tool used to obtain information for interpreting the results. Percentage effect of factors on the response can be calculated individually by this analysis (Abdessalem et al., 2008). Due to this reason, in recent years it has been applied in optimization of waste water treatment processes involving multi-factors (Anupam et al., 2011).

In this work, CCD method was used to optimize the process variables for treatment of food industry effluents. Electrocoagulation process was applied to remove chemical oxygen demand (COD) from the wastewater. In this process, $\mathrm{pH}$, conductivity, current density and duration period were selected as the system variables. Optimization studies were individually performed for COD removal and electricity consumption costs.

\section{Materials and methods}

\subsection{Experimental set-up and procedure}

In this study, electrocoagulation process was performed to remove COD since it is a simple and efficient method for treatment of many pollutants. The wastewater used in the experiments was supplied by a treatment plant of a potato chips manufacturing factory. The samples were taken from the outlet of the anaerobic treatment section. Here, we evaluated electrocoagulation as an alternative to conventional aerobic treatment.

The characterization studies were performed to determine the composition of the studied wastewater. The COD and the total organic carbon (TOC) contents of the sample were measured as 500 and $100 \mathrm{mg} / \mathrm{L}$ respectively, and the total suspended solid (TSS) parameter was determined as $145 \mathrm{mg} / \mathrm{L}$. The conductivity and $\mathrm{pH}$ of the wastewater was also analyzed as important parameters for electrocoagulation process and they were found to be $3.40 \mathrm{mS} / \mathrm{cm}$ and 7.8 respectively. The characterization analysis was conducted according to the Standard Methods (APHA, 2012).

Electrocoagulation tests were performed by using a set-up consisted of a batch electrocoagulation tank and a power source (MERSAN MR 12). Electrocoagulation tank has the dimensions of $15 \times 15 \times 15 \mathrm{~cm}$ and the sample volume capacity of $2 \mathrm{~L}$. The scheme of the experimental set-up has been presented in Figure 1.

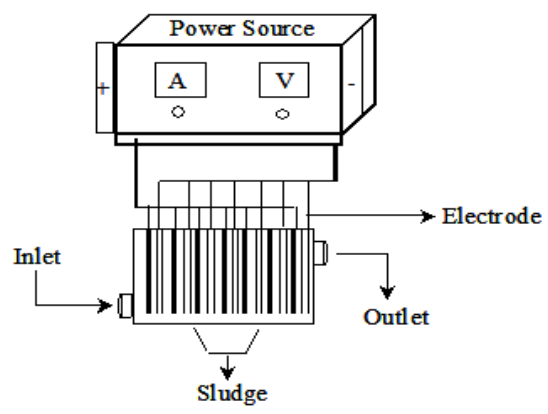

Figure 1. Experimental set-up of electrocoagulation
During experiments Al electrodes with $99.52 \%$ purity were used. 14 plates with surface area of $11 \times 16$ were placed into the reactor. The electrodes were connected to a direct current power supply.

Before electrocoagulation tests, the electrodes were kept in \% $\mathrm{HCl}$ for 8 hours. During the experiments, $2 \mathrm{~L}$ of the wastewater sample was placed into the electrolytic cell. The $\mathrm{pH}$ of the samples were adjusted by using $0.1 \mathrm{~N} \mathrm{HCl} / \mathrm{NaOH}$ whereas conductivity was adjusted by $0.1 \mathrm{~N} \mathrm{Na}_{2} \mathrm{SO}_{4}$. The current density was set to the predetermined value. All the experiments were performed at room temperature.

\subsection{Statistical design of the experiments}

In this study, central composite design (CDD) was used to evaluate the impacts of the selected independent variables $\left(\mathrm{pH}: \mathrm{x}_{1}\right.$, conductivity: $\mathrm{x}_{2}$, current density: $\mathrm{x}_{3}$ and detention time: $x_{4}$ ) on the response variable (COD removal). With this aim, the experiments were conducted based on four-factor, five-level central composite rotatable design technique. Thus, each independent variable was coded at five levels, from -2 to +2 , as shown in Table 1 . The determination of the factors used in this study was based on previous experimental studies and literature (Tezcan Un et al., 2009; Veli et al., 2016).

Table 1. Experimental ranges and levels of the studied factors

\begin{tabular}{ccccccc}
\hline Parameter & Units & $\mathbf{- 2}$ & $\mathbf{- 1}$ & $\mathbf{0}$ & $\mathbf{+ 1}$ & $\mathbf{+ 2}$ \\
\hline $\mathrm{pH}$ & - & 4 & 5 & 6 & 7 & 8 \\
\hline Conductivity & $\mathrm{mS} / \mathrm{cm}$ & 3.50 & 3.75 & 4.00 & 4.25 & 4.50 \\
\hline Current & $\mathrm{mA} / \mathrm{cm}^{2}$ & 1.01 & 1.22 & 1.42 & 1.62 & 1.82 \\
\hline Time & $\mathrm{min}$ & 6 & 12 & 18 & 24 & 30 \\
\hline
\end{tabular}

Minitab 16 software package was used for experimental design applications. The developed quadratic model with this software provided information about both individual and interactive effects of process variables.

\section{Results and discussion}

\subsection{Results of experimental design procedure}

In this work, total 31 experiments were designed using CCD technique. Experimental conditions and obtained response values in each experimental run have been presented in Table 2.

COD removal efficiencies have been calculated with the following simple expression:

Removal efficiency $(\%)=\frac{C_{i}-C_{0}}{C_{0}} \times 100$

where $C_{i}$ and $C_{0}$ denote the initial and final COD concentrations of the samples respectively.

As seen from Table 2, the developed central composite design provided the highest COD removal efficiency of $78 \%$ by $23^{\text {rd }}$ run. Coded levels of the $\mathrm{pH}$, conductivity, current density and time were all +1 for this run. Interactions between the independent variables and the response variable have been discussed in Section 3.4 in detail. 
Table 2. Design of the experiments by CDD

\begin{tabular}{|c|c|c|c|c|c|c|}
\hline Run & $\mathrm{pH}$ & $\begin{array}{l}\text { Conductivity } \\
(\mathrm{mS} / \mathrm{cm})\end{array}$ & $\begin{array}{l}\text { Current } \\
\text { density } \\
(\mathrm{mA} / \\
\left.\mathrm{cm}^{2}\right)\end{array}$ & $\begin{array}{l}\text { Time } \\
\text { (min) }\end{array}$ & $\begin{array}{c}\text { COD } \\
\text { removal } \\
(\%)\end{array}$ & $\begin{array}{c}\text { Energy } \\
\text { cost } \\
\text { (\$/g COD } \\
\text { removal) }\end{array}$ \\
\hline 1 & 5 & 3.75 & 1.62 & 12 & 45 & 0.96 \\
\hline 2 & 6 & 4.00 & 1.42 & 18 & 55 & 0.94 \\
\hline 3 & 7 & 3.75 & 1.62 & 12 & 59 & 0.66 \\
\hline 4 & 5 & 3.75 & 1.62 & 24 & 58 & 1.44 \\
\hline 5 & 6 & 4.50 & 1.42 & 18 & 57 & 0.73 \\
\hline 6 & 6 & 4.00 & 1.42 & 18 & 56 & 0.83 \\
\hline 7 & 6 & 4.00 & 1.01 & 18 & 44 & 0.50 \\
\hline 8 & 5 & 4.25 & 1.62 & 12 & 48 & 0.83 \\
\hline 9 & 5 & 3.75 & 1.22 & 12 & 27 & 0.76 \\
\hline 10 & 6 & 4.00 & 1.42 & 18 & 56 & 0.83 \\
\hline 11 & 6 & 4.00 & 1.42 & 18 & 57 & 0.82 \\
\hline 12 & 7 & 4.25 & 1.22 & 12 & 45 & 0.42 \\
\hline 13 & 7 & 3.75 & 1.22 & 24 & 60 & 1.03 \\
\hline 14 & 7 & 3.75 & 1.22 & 12 & 47 & 0.64 \\
\hline 15 & 7 & 4.25 & 1.22 & 24 & 68 & 0.56 \\
\hline 16 & 6 & 3.50 & 1.42 & 18 & 51 & 0.98 \\
\hline 17 & 6 & 4.00 & 1.82 & 18 & 65 & 1.08 \\
\hline 18 & 5 & 3.75 & 1.22 & 24 & 28 & 1.44 \\
\hline 19 & 6 & 4.00 & 1.42 & 18 & 54 & 0.86 \\
\hline 20 & 7 & 3.75 & 1.62 & 24 & 74 & 1.06 \\
\hline 21 & 7 & 4.25 & 1.62 & 12 & 57 & 0.58 \\
\hline 22 & 6 & 4.00 & 1.42 & 18 & 57 & 0.82 \\
\hline 23 & 7 & 4.25 & 1.62 & 24 & 78 & 0.75 \\
\hline 24 & 5 & 4.25 & 1.22 & 12 & 35 & 0.49 \\
\hline 25 & 6 & 4.00 & 1.42 & 18 & 54 & 0.98 \\
\hline 26 & 6 & 4.00 & 1.42 & 6 & 25 & 0.72 \\
\hline 27 & 8 & 4.00 & 1.42 & 18 & 60 & 0.92 \\
\hline 28 & 5 & 4.25 & 1.62 & 24 & 58 & 1.37 \\
\hline 29 & 6 & 4.00 & 1.42 & 30 & 66 & 1.34 \\
\hline 30 & 5 & 4.25 & 1.22 & 24 & 56 & 0.72 \\
\hline 31 & 4 & 4.00 & 1.42 & 18 & 27 & 1.52 \\
\hline
\end{tabular}

In this study, an economic analysis of the experiment was also performed for the process. Cost calculations that were made for unit COD removal is based on electricity consumption, since energy is the most expensive item of the electrocoagulation processes. Energy consumptions ( $C_{\text {energy }}$ ) per unit volume $\left(\mathrm{m}^{3}\right)$ of the treated wastewater were determined by using the following equation:

$C_{\text {energy }}=\frac{\mathrm{V} \times \mathrm{I} \times \mathrm{t}}{\mathrm{V}}$

where $V$ shows the applied voltage value $(\mathrm{V}), \mathrm{I}$ is the current $(A), t$ is detention time $(s)$, and $v$ is the volume of treated wastewater. Calculated $\mathrm{C}_{\text {energy }}$ values have been multiplied by unit electricity cost in Turkey $(0.12 \$ / K w h)$. Finally, the calculated cost has been divided by the amount of removed COD (g) to obtain energy cost per unit COD removal (\$/g COD removal).

The highest and lowest energy costs per unit COD removal have been obtained for $31^{\text {st }}$ and $12^{\text {th }}$ experimental runs (Table 2). Considering the corresponding COD removal efficiencies, it is clearly seen that higher energy cost does not yield higher removal efficiencies. This result indicates the importance of energy cost optimization for this process.

By using data provided by the proposed experimental design, CCD approach develops second order surface model to predict the targeted responses $(y)$. The general expression for the quadratic regression model is given below:

$\mathrm{y}=\beta_{0}+\sum_{\mathrm{i}=1}^{\mathrm{k}} \beta_{\mathrm{i}} \mathrm{x}_{\mathrm{i}}+\sum_{\mathrm{i}=1}^{\mathrm{k}} \beta_{\mathrm{ii}} \mathrm{x}_{\mathrm{i}}^{2}+\sum_{\mathrm{i}=1}^{\mathrm{k}-1} \sum_{\mathrm{i}=1}^{\mathrm{k}} \beta_{\mathrm{ij}} \mathrm{x}_{\mathrm{i}} \mathrm{xj}+\varepsilon$

In the equation $\beta_{0},\left(\beta_{1}, \beta_{2}, \beta_{3}\right),\left(\beta_{12}, \beta_{12}, \beta_{23}\right)$ and $\left(\beta_{11}, \beta_{22}\right.$, $\left.\beta_{33}\right)$ are the intercept, linear, interaction and quadratic regression coefficients, respectively. $k$ represents the number of factors and $\varepsilon$ shows the random error of the model (Gengec et al., 2013).

In this study, following regression models were obtained to predict COD removal efficiencies (Eq 4) and energy consumption costs (Eq 5), considering both individual and interactive effects of $\mathrm{pH}\left(\mathrm{x}_{1}\right)$, conductivity $\left(\mathrm{x}_{2}\right)$, current $\left(\mathrm{x}_{3}\right)$, and time $\left(\mathrm{x}_{4}\right)$ in terms of coded factors.

COD removal $(\%)=-512.95+70.48 x_{1}+76.88 x_{2}+$ $223.88 x_{3}-3.91 x_{4}-2.47 x_{1}^{2}+2.55 x_{2}^{2}+7.11 x_{3}^{2}-$ $0.06 x_{4}^{2}-7.75 x_{1} x_{2}-4.69 x_{1} x_{3}+0.28 x_{1} x_{4}-$ $46.25 x_{2} x_{3}+1.38 x_{2} x_{4}+0.05 x_{3} x_{4}$

Cost $(\$ /$ removal g COD $)=0.0191-0.571 \mathrm{x}_{1}+$ $1.019 x_{2}-0.759 x_{3}+0.195 x_{4}+0.068 x_{1}^{2}-$ $0.366 x_{2}^{2}-0.978 x_{3}^{2}+0.0006 x_{4}^{2}+0.028 x_{1} x_{2}-$ $0.247 x_{1} x_{3}-0.009 x_{1} x_{4}+1.363 x_{2} x_{3}-0.036 x_{2} x_{4}+$ $0.008 \times_{3} x_{4}$

The developed models represented by Eq (4) and Eq (5) provided good prediction efficiencies for corresponding resp"onses. $R^{2}$ values were determined as 0.95 and 0.92 for COD removal (Figure 2a) and energy costs (Figure 2b) models, respectively.

\subsection{Analysis of variance (ANOVA)}

Even though high correlation coefficients indicated the appropriateness of the developed predictive models obtained, analysis of variance (ANOVA) was also performed to examine the adequacy and significance of the models.

Statistical parameters obtained from the ANOVA for the models have been presented in Table 3 .

Results of the ANOVA tests have confirmed the appropriateness of the obtained quadratic models. The $p$-values of the models, which are $<0.05$, indicate statistical significance (Ahmadi et al., 2005; Saini and Kumar, 2016). In addition, F-values of the regression models are significantly higher than tabulated $F(2.352)$ at $95 \%$ significance. This result also confirms the accuracy of the models (Hassani et al., 2016). 


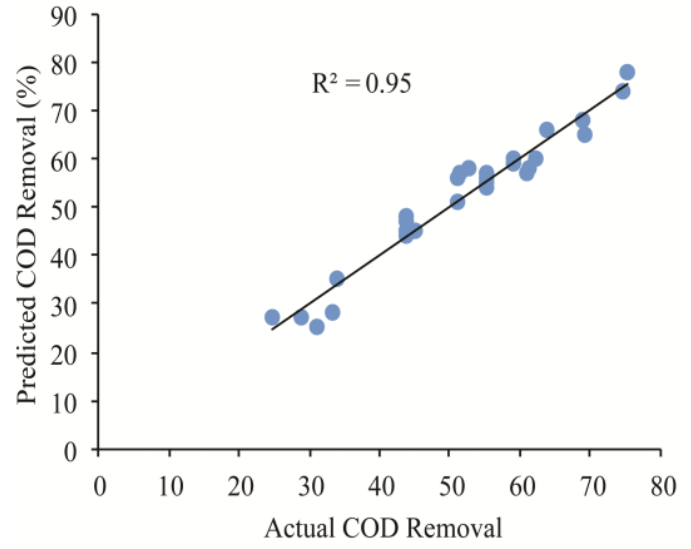

(a)

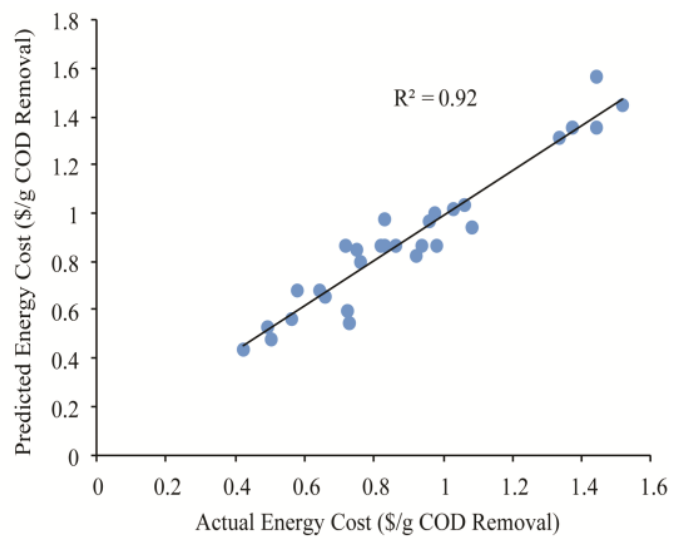

(b)

Figure 2. Predictive models for a) COD removal and b) energy costs

Table 3. Analysis of variance for a) COD removal and b) energy consumption costs

\begin{tabular}{|c|c|c|c|c|c|c|c|c|c|c|c|}
\hline \multirow{2}{*}{ Source } & \multirow{2}{*}{ DF } & \multicolumn{2}{|c|}{ Seq SS } & \multicolumn{2}{|c|}{ Adj SS } & \multicolumn{2}{|c|}{ Adj MS } & \multicolumn{2}{|c|}{$F$} & \multicolumn{2}{|c|}{$\mathbf{P}$} \\
\hline & & a & b & $\mathbf{a}$ & b & $a$ & b & $\mathbf{a}$ & b & a & b \\
\hline Regression & 14 & 4974.44 & 2.341 & 4974.44 & 2.341 & 355.317 & 0.167 & 21.76 & 13.53 & 0.000 & 0.000 \\
\hline Linear & 4 & 4420.50 & 1.908 & 290.33 & 0.080 & 72.581 & 0.020 & 4.44 & 1.62 & 0.013 & 0.218 \\
\hline Square & 4 & 280.57 & 0.227 & 280.57 & 0.227 & 70.142 & 0.057 & 4.30 & 4.60 & 0.015 & 0.012 \\
\hline Interaction & 6 & 273.37 & 0.206 & 273.37 & 0.206 & 45.562 & 0.034 & 2.79 & 2.78 & 0.047 & 0.048 \\
\hline Residual error & 16 & 261.30 & 0.198 & 261.30 & 0.198 & 16.331 & 0.012 & & & & \\
\hline Lack of fit & 10 & 251.58 & 0.172 & 251.58 & 0.172 & 25.158 & 0.017 & 15.54 & 4.09 & 0.002 & 0.049 \\
\hline Pure error & 6 & 9.71 & 0.025 & 9.71 & 0.025 & 1.619 & 0.004 & & & & \\
\hline Total & 30 & 5235.74 & 2.539 & & & & & & & & \\
\hline
\end{tabular}

In this study, the Pareto analysis was also performed to determine the percentage effect of independent variable on the response. The following expression was used for Pareto calculations (Khataee et al., 2010):

$P_{i}=\left(\frac{b_{i}^{2}}{\sum_{i=1}^{n} b_{i}^{2}}\right) \times 100(i \neq 0)$

In the equation, $b_{i}$ represents the regression coefficients in quadratic model equations.

Pareto analysis was applied to both of the models developed for predicating COD removal and energy consumption costs. It was observed that current density has been the most effective factor $(79.18 \%)$ on the COD removal. It was followed by conductivity $(9.34 \%)$ and $\mathrm{pH}$ (7.85\%).

Results of Pareto analysis showed that individual impacts of $\mathrm{pH}$, conductivity, current density and electrolysis period on energy consumption costs are $6.53 \%, 20.79 \%, 11.53 \%$ and $0.76 \%$, respectively. Among the interactive impacts, current density $\mathrm{x}$ conductivity has the highest effect on energy cost with $37.20 \%$.

\subsection{Validation of the model}

Additional experiments were performed to validate the model. With this aim, 12 different experimental runs were decided which were not used previously (Table 4).

Table 4. Design of the experiments for validation tests

\begin{tabular}{ccccccc}
\hline Run & $\mathbf{p H}$ & $\begin{array}{c}\text { Conductivity } \\
(\mathbf{m S} / \mathbf{c m})\end{array}$ & $\begin{array}{c}\text { Current } \\
\left(\mathbf{m A} / \mathbf{c m}^{2}\right)\end{array}$ & $\begin{array}{c}\text { Time } \\
(\mathbf{m i n})\end{array}$ & \multicolumn{2}{c}{ COD Removal (\%) } \\
\cline { 6 - 7 } & & & $\begin{array}{c}\text { Actual } \\
\text { value }\end{array}$ & $\begin{array}{c}\text { Predicted } \\
\text { Value }\end{array}$ \\
\hline 1 & 3 & 3.5 & 1.82 & 10 & 22 & 18.84 \\
\hline 2 & 3 & 3.5 & 1.82 & 15 & 25 & 21.15 \\
\hline 3 & 3 & 3.5 & 1.82 & 20 & 28 & 20.70 \\
\hline 4 & 5 & 3.5 & 1.82 & 10 & 48 & 54.64 \\
\hline 5 & 5 & 3.5 & 1.82 & 15 & 52 & 59.79 \\
\hline 6 & 5 & 3.5 & 1.82 & 20 & 58 & 62.12 \\
\hline 7 & 7 & 3.5 & 1.82 & 10 & 56 & 70.71 \\
\hline 8 & 7 & 3.5 & 1.82 & 15 & 78 & 78.64 \\
\hline 9 & 7 & 3.5 & 1.82 & 20 & 78 & 83.82 \\
\hline 10 & 7 & 3.5 & 1.02 & 10 & 33 & 30.80 \\
\hline 11 & 7 & 3.5 & 1.42 & 20 & 58 & 62.51 \\
\hline 12 & 7 & 3.5 & 1.82 & 30 & 89 & 85.92 \\
\hline & & & & & & \\
\hline
\end{tabular}

COD removal efficiencies were measured and also predicted by using previously obtained predictive model (Eq 4). A high correlation coefficient was determined for the relationship between the predicted and actual COD 
removal efficiencies. $\mathrm{R}^{2}$ value of 0.95 demonstrates the validity of our model (Figure 3 ).

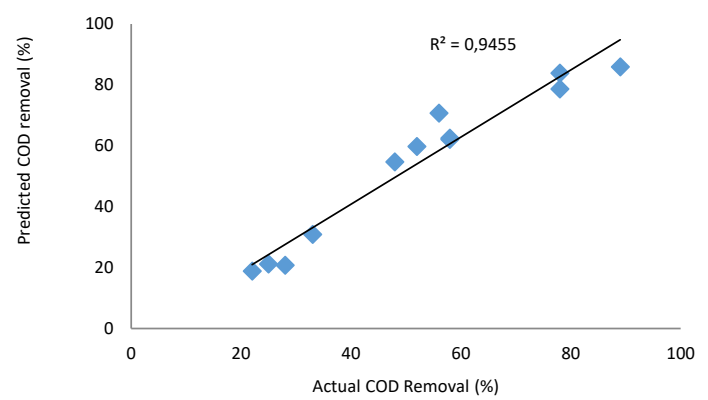

Figure 3. Validation of RSM model for COD removal

\subsection{Response surface plots for COD removal efficiency}

In this study, the interactions between dependent and independent process variables were investigated by using response surface plots. In order to examine bivariate interactions, hold values are decided to be as $\mathrm{pH}=6$, conductivity $=4$, current $=1.42$ and time: $18 \mathrm{~min}$.

When $\mathrm{pH}$ interactions are investigated, it is clearly seen from the corresponding figures that (Figure 4 b,c,d) effective COD removal has been achieved for $\mathrm{pH}$ values between 6 and 7.5. This result is in good agreement with the literature. This $\mathrm{pH}$ values yielded formation of monomeric and polymeric aluminum complexes such as $\mathrm{Al}(\mathrm{OH})_{3}, \quad \mathrm{Al}(\mathrm{OH})^{2+}, \quad \mathrm{Al}_{17}(\mathrm{OH})_{32^{7+}}$ which are effective coagulants improving the performance of electrocoagulation processes (Martinez-Huitle and Brillas, 2009). Impact of $\mathrm{pH}$ is more significant especially for lower conductivity conditions (Chen, 2004). Results of our study have also confirmed this knowledge (Figure 4b).

Similar to many other chemical processes, duration period is an important process variable for electrocoagulation. This process starts with the neutralization of particles by ions released from the electrodes and followed by coagulation. Increase in the electrolysis period increases the released ion concentration and in this way, formation of hydroxyl flocks are improved (Daneshvar et al., 2004). In our study, reaction periods longer than 20 minutes provided sufficient COD removal efficiencies (>70\%) (Figure 4a, d, e).

In electrocoagulation systems, current density determines the released metal ion dose. Increase in current density yields improvement in ion production and consequently better flocculation efficiencies (Daneshvar et al., 2004). This fact can also be proved by Faraday's Law which is useful for determining maximum dissolved mass (g) of anode material (m) (Gatsios et al., 2015):

$$
\mathrm{m}=\frac{\mathrm{I} \times \mathrm{t} \times \mathrm{M}_{\mathrm{a}}}{\mathrm{F} \times \mathrm{z}}
$$

In the equation $\mathrm{I}, \mathrm{t}$ and $\mathrm{M}_{\mathrm{a}}$ represent applied current (A), electrolysis period ( $\mathrm{s}$ ) and specific molecular weight of anode material $(\mathrm{g} / \mathrm{mol})$ respectively. $\mathrm{F}$ shows Faraday's constant $(96,485.34 \mathrm{As} / \mathrm{mol})$ and $z$ is the number of electrons in the reaction. As seen from the Eq (7), mass of the dissolved anode material is proportional with both current density and time. Undoubtedly, high current densities will improve the electrocoagulation efficiencies. In order to achieve a predetermined mass of a certain anode material, adjustment can be made between electrolysis period and current density. In other words efficient treatment can be achieved by applying high currents for shorter periods or vice versa. Considering the fact that electrolysis period and/or current density are the most important parameters influencing the operational costs, it is clearly seen that optimization is mandatory. As seen from Figure $4 a$, in order to achieve sufficient treatment (higher than 70\%) current density should be higher than 1.6. This value can be decreased by increasing electrolysis period.

Conductivity of solution is another important parameter in electrocoagulation processes affecting the current efficiency and energy consumption (Daneshvar et al., 2006). When surface plots involving conductivity is investigated, the positive impact of conductivity can be clearly seen (Figure 4b, e, f).

According to literature, it was observed that $60-89 \%$ COD removal efficiency was obtained in EC studies with $\mathrm{Al}$ electrode carried out with different contaminant sources and this is consistent with the results obtained in this study (Table 5).

\subsection{Response surface plots for energy costs}

In this study, energy consumption costs are analyzed by using response surface plots (Figure 5). Similar to previous applications, hold values were determined to be medium ones $(\mathrm{pH}=6$, conductivity=4, current=1.42 and time: $18 \mathrm{~min})$.
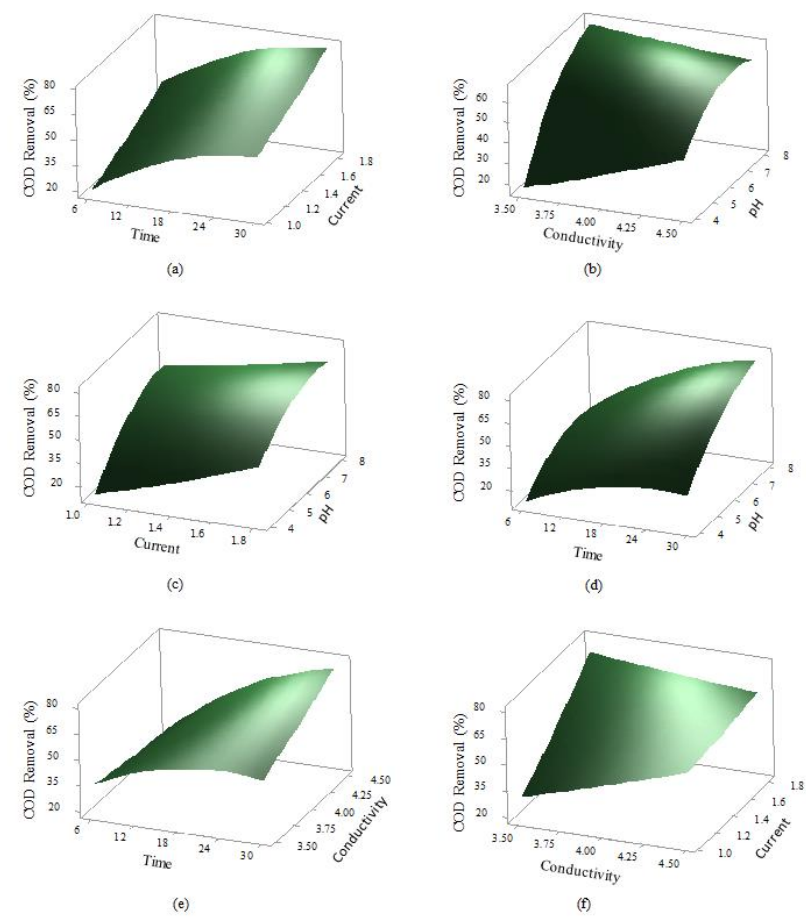

Figure 4. Surface plots for COD removal efficiency as a function of a) current density and time b) $\mathrm{pH}$ and conductivity c) $\mathrm{pH}$ and current density d) $\mathrm{pH}$ and time e) conductivity and time f) conductivity and current density 
As seen from Figure 5a, energy consumption costs $(\$)$ per unit COD removal $(\mathrm{g})$ can be minimized by adjusting $\mathrm{pH}$ to 6-7 and applying low current densities $\left(<1.1 \mathrm{~mA} / \mathrm{cm}^{2}\right)$. It is clearly seen from Figure $5 b$ that high conductivity $(>4.25 \mathrm{mS} / \mathrm{cm})$ provides cost-effective treatment options (<0.2\$/g COD removed).

Table 5. Al electrod ile elde edilen COD verimleri

\begin{tabular}{|c|c|c|c|c|}
\hline $\begin{array}{l}\text { Pollution } \\
\text { sources }\end{array}$ & $\begin{array}{l}\text { Current } \\
\text { density } \\
\left(\mathrm{A} / \mathrm{m}^{2}\right)\end{array}$ & $\begin{array}{c}\text { Reaction } \\
\text { time } \\
\text { (min) }\end{array}$ & $\begin{array}{c}\text { COD } \\
\text { removal } \\
(\%) \\
\end{array}$ & Reference \\
\hline $\begin{array}{c}\text { Urban } \\
\text { wastewater }\end{array}$ & 200 & 30 & 85 & $\begin{array}{c}\text { Elazzouzi et } \\
\text { al., } 2017\end{array}$ \\
\hline $\begin{array}{c}\text { Real } \\
\text { dyehouse } \\
\text { wastewater }\end{array}$ & 65 & 80 & 77 & $\begin{array}{l}\text { Kobya et } \\
\text { al., } 2016\end{array}$ \\
\hline $\begin{array}{l}\text { Biologically } \\
\text { treated } \\
\text { municipal } \\
\text { wastewater }\end{array}$ & 75.2 & 40 & 86 & $\begin{array}{c}\text { Chopra and } \\
\text { Sharma, } \\
2015\end{array}$ \\
\hline Leachate & 200 & 60 & 60.5 & $\begin{array}{l}\text { Kabuk et } \\
\text { al., } 2014\end{array}$ \\
\hline $\begin{array}{c}\text { Egg } \\
\text { processing } \\
\text { effluent }\end{array}$ & 200 & 30 & 89 & $\begin{array}{c}\text { Sridhar et } \\
\text { al., } 2014\end{array}$ \\
\hline $\begin{array}{c}\text { Domestic } \\
\text { wastewater }\end{array}$ & 100 & 10 & 72 & $\begin{array}{c}\text { Ozyonar } \\
\text { and } \\
\text { Karagozoğl } \\
\text { u, } 2011\end{array}$ \\
\hline $\begin{array}{c}\text { Textile } \\
\text { wastewater }\end{array}$ & 100 & 60 & 88 & $\begin{array}{l}\text { Zongo et. } \\
\text { al., } 2009\end{array}$ \\
\hline $\begin{array}{c}\text { Potato } \\
\text { chips } \\
\text { manufactur } \\
\text { ing } \\
\text { wastewater }\end{array}$ & $15-18$ & $15-30$ & $70-89$ & This study \\
\hline
\end{tabular}

The current density and electrolysis period are the most effective parameters on energy consumption cost. Low energy costs can be achieved by decreasing time periods ( $<15 \mathrm{~min})$ and current density $\left(<1.1 \mathrm{~mA} / \mathrm{cm}^{2}\right)$ that is shown in Figure $5 c$.

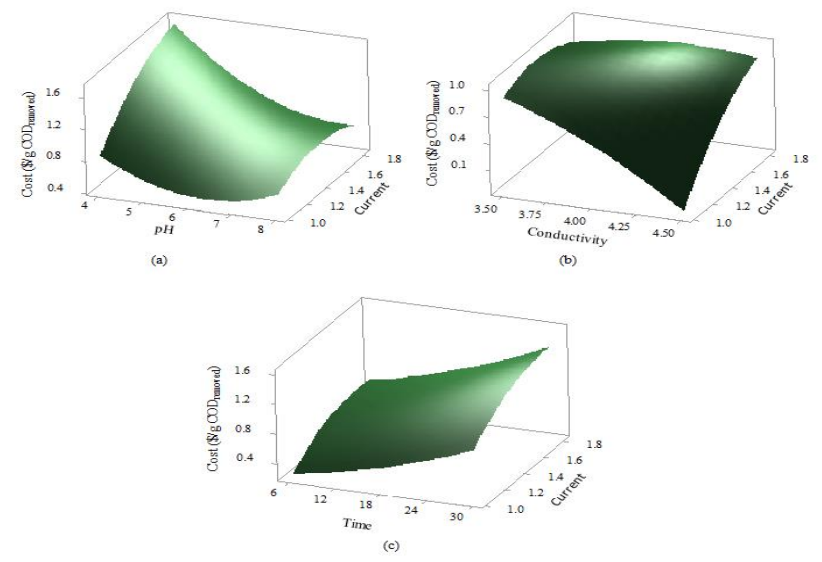

Figure 5. Surface plots for energy consumption costs as a function of a) $\mathrm{pH}$ and current density b) current density and conductivity c) current density and time

\section{Conclusions}

The objectives of this study were to optimize the COD removal efficiencies and energy consumption costs for treatment of food wastewaters by electrocoagulation process. With this aim central composite design method was applied and predictive quadratic models were developed for both of the responses. The accuracy of the models was confirmed by both high $R^{2}$ values (0.95 and 0.92 for COD removal and energy cost prediction, respectively) and ANOVA tests. $p$ values obtained from ANOVA analysis were lower than 0.05 for both of the regression equations demonstrating the appropriateness of the models. Accuracy of the model developed for predicting COD removal was also confirmed by the conducted validation tests. $R^{2}$ of validation was also sufficient (0.95). In this study, impacts of process parameters on response values were determined numerically by Pareto analysis. Current density was found to be the most effective factor $(79.18 \%)$ on COD removal whereas current density $x$ conductivity has the highest impact $(37.20 \%)$ on energy consumption costs.

According to the legal regulations in Turkey (WPCA, 2004) limit value of COD parameter for vegetable and fruit processing sector is set to be $150 \mathrm{mg} / \mathrm{L}$. In order to achieve discharge limit, 70\% COD treatment efficiency is targeted for the studied wastewater. Results of the study showed that optimum treatment can be provided by applying $1.5 \mathrm{~mA} / \mathrm{cm}^{2}$ current density for $20 \mathrm{~min}$ electrolysis period under original $\mathrm{pH}(7.8)$ and conductivity $(3.40 \mathrm{mS} / \mathrm{cm})$. Energy consumption cost has been determined as $0.9 \$ / g$ COD removal for these conditions.

\section{Acknowledgements}

This study was supported by Scientific Research Unit of Kocaeli University (Project No.: BAP 2016/012). The authors express special thanks to Muhammed Veli for his helpful suggestions.

\section{References}

Anupam K., Dutta S., Bhattacharjee C. and Datta S. (2011), Adsorptive removal of chromium (VI) from aqueous solution over powdered activated carbon: Optimization through response surface methodology, Chemical Engineering Journal, 173, 135-143.

Abdessalem A.K., Oturan N., Bellakhal N., Dachraoui M., Oturan M.A. (2008), Experimental design methodology applied to electro-Fenton treatment for degradation of herbicide chlortoluron, Applied Catalysis B-Environmental, 78, 334341.

Ahmadi M., Vahabzadeh F., Bonakdarpour B., Mofarrah E. and Mehranian M. (2005), Application of the central composite design and response surface methodology to the advanced treatment of olive oil processing wastewater using Fenton's peroxidation, Journal of Hazardous Materials, 123, 187-195.

APHA. (2012), Standard Methods for the Examination of Water and Wastewater, American Public Health Association Washington, DC.

Chen G. (2004), Electrochemical technologies in wastewater treatment, Seperation and Purification Technology, 38(1), 11-41. 
Chopra A.K. and Sharma A.K. (2015), Effect of electrochemical treatment on the COD removal from biologically treated municipal wastewater, Desalination and Water Treatment, 53, 41-47.

Daneshvar N., Oladegaragoze A. and Djafarzadeh N. (2006), Decolorization of basic dye solutions by electrocoagulation: An investigation of the effect of operational parameters, Journal of Hazardous Materials, 129, 116-122.

Daneshvar N., Sorkhabi H.A. and Kasiri M.B. (2004), Decolorization of dye solution containing Acid Red 14 by electrocoagulation with a comparative investigation of different electrode connections, Journal of Hazardous Materials, 112, 55-62.

Dashamiri S., Ghaedi M., Dashtian K., Rahimi M.R., Goudarzi A. and Jannesar R. (2016), Ultrasonic enhancement of the simultaneous removal of quaternary toxic organic dyes by CuO nanoparticles loaded on activated carbon: Central composite design, kinetic and isotherm study, Ultrasonics Sonochemistry, 31, 546-557.

Dongxia Y., Xiaoyan L., Dingyong H., Zuoren N. and Hui H. (2012), Optimization of weld bead geometry in laser welding with filler wire process using Taguchi's approach, Optics and Laser Technology, 44, 2020-2025.

Elazzouzi M., Haboubi Kh. and Elyoubi M.S. (2017), Electrocoagulation flocculation as a low-cost process for pollutants removal from urban wastewater, Chemical Engineering Research and Design, 117, 614-626.

Elizalde-González M.P. and García-Díaz L.E. (2010), Application of a Taguchi L16 orthogonal array for optimizing the removal of Acid Orange 8 using carbon with a low specific surface area, Chemical Engineering Journal, 163, 55-61.

Gengec E., Ozdemir U., Ozbay B., Ozbay I. and Veli S. (2013), Optimizing Dye Adsorption Onto a Waste-Derived (Modified Charcoal Ash) Adsorbent Using Box-Behnken and Central Composite Design Procedures, Water Air Soil Polluton, DOI: 10.1007/s11270-013-1751-6.

Hassani A., Soltani R.D.C., Kıranşan M., Karaca S., Karaca C. and Khataee A. (2016), Ultrasound-assisted adsorption of textile dyes using modified nanoclay: Central composite design optimization, Korean Journal of Chemical Engineering, 33(1), 178-188.

Kabuk H.A., Ilhan F., Avsar Y., Kurt U., Apaydin O. and Gonullu M.T. (2013), Investigation of leachate treatment with electrocoagulation and optimization by Response Surface Methodology, Clean - Soil, Air, Water, 42(5), 571-577.

Khataee A.R., Fathinia M., Aber S. and Zarei M. (2010), Optimization of photocatalytic treatment of dye solution on supported $\mathrm{TiO}_{2}$ nanoparticles by central composite design: Intermediates identification, Journal of Hazardous Materials, 181, 886-897.

Kobya M., Gengec E. and Demirbas E. (2016), Operating parameters and costs assessments of a real dyehouse wastewater effluent treated by a continuous electrocoagulation process, Chemical Engineering and Processing: Process Intensification, 101, 87-100.

Martinez-Huitle C.A. and Brillas E. (2009), Decontamination of wastewaters containing synthetic organic dyes by electrochemical methods: A general review, Applied Catalysis B-Environmental, 87, 105-145.

Nikzad M., Movagharnejad K., Farid T., Aghaiy Z. and Mighani M. (2015), Modeling of alkali pretreatment of rice husk using response surface methodology and artificial neural network, Chemical Engineering Communications, 202, 728-738.

Ozyonar F. and Karagozoglu B. (2011), Operating cost analysis and treatment of domestic wastewater by electrocoagulation using aluminum electrodes, Polish Journal of Environmental Studies, 20(1), 173-179.

Pakravan P., Akhbari A., Moradi H., Azandaryani A.H., Mansouri A.M. and Safari M. (2015), Process modeling and evaluation of petroleum refinery wastewater treatment through response surface methodology and artificial neural network in a photocatalytic reactor using poly ethyleneimine (PEI)/titania $\left(\mathrm{TiO}_{2}\right)$ multilayer film on quartz tube, Applied Petrochemical Research, 5, 47-59.

Raj B.B.C. and Quen H.L. (2005), Advanced oxidation processes for wastewater treatment: Optimization of $\mathrm{UV} / \mathrm{H}_{2} \mathrm{O}_{2}$ process through a statistical technique, Chemical Engineering Science, 60, 5305-5311.

Rathinam A., Rao J.R. and Nair B.U. (2011), Adsorption of phenol onto activated carbon from seaweed: Determination of the optimal experimental parameters using factorial design, Journal of the Taiwan Institute of Chemical Engineers, 42, 952-956.

Saini R. and Kumar P. (2016), Simultaneous removal of methyl parathion and chlorpyrifos pesticides from model wastewater using coagulation/flocculation: Central composite design, Journal of Environmental Chemical Engineering, 4, 673-680.

Sridhar R., Sivakumar V., Maran J.P. and Thirugnanasambandham K. (2014), Influence of operating parameters on treatment of egg processing effluent by electrocoagulation process, International Journal of Environmental Science and Technology, 11, 1619-1630.

Tsui K.L. (1996), A critical look at Taguchi's modelling approach for robust design, Journal of Applied Statistics, 23(1), 81-95.

Un U.T., Koparal A.S. and Ogutveren U.B. (2009), Electrocoagulation of vegetable oil refinery wastewater using aluminum electrodes, Journal of Environmental Management, 90, 428-433.

Veli S., Arslan A. and Bingöl D. (2016), Application of response surface methodology to electrocoagulation treatment of hospital wastewater, Clean-Soil Air Water, 44(11), 1516-1522.

Wang J. and Wan W. (2009), Experimental design methods for fermentative hydrogen production: A review, International Journal of Hydrogen Energy, 34, 235-244.

WPCA (2004). Water Pollution Control Act, Ministry of Environment and Forestry, Ankara, Turkey.

Zongo I., Maiga A.H., Wéthé J. Valentin G., Leclerc J-P., Paternotte G. and Lapicque F. (2009), Electrocoagulation for the treatment of textile wastewaters with $\mathrm{Al}$ and $\mathrm{Fe}$ electrodes: Compared variations of COD levels, turbidity and absorbance, Journal of Hazardous Materials, 169, 70-76. 